\title{
Improving the Quality of Human Resources in Indigenous Village Institutions Through Work Culture Based on "Catur Marga" in Bali Aga Village, Buleleng Regency
}

\section{Luh Kartika Ningsih $^{1 *}$, Ni Luh Putu Eka Yudi Prastiwi ${ }^{2}$}

1,2 Sekolah Tinggi Ilmu Ekonomi Satya Dharma Singaraja

\section{A R T I C L E I N F 0}

Article history:

Received 19 May 2019

Received in revised form

16 June 2019

Accepted 15 July 2019

Available online 29 August

2019

Keywords:

Catur Marga-Based Culture

Work, Human Resource

Management, Work

Productivity

\section{A B S T R A C T}

This study aims to determine the improvement of human resources quality of the Village Institution through Catur Marga-based Work Culture in Bali Aga Village, Buleleng Regency. A quantitative approach will be used in this study. The data analysis technique used in this study was SEM PLS Version 3.0. The sample is 135 people with ttable values for the significance level $\alpha=0.05$ of 1.960 . The results showed that there was a positive and significant result in all relationships where the Effect of Catur Marga-based Work Culture on HRM was 4.477. Likewise, the Effect of Catur Marga-based Work Culture on Work Productivity was 31.010, and the relationship of Human Resource Management to Work Productivity was 7.338. From the results, it can be concluded that Catur Marga- based culture work has a positive role because it can provide good results for improving the Quality of Human Resource Management and Work Productivity.

\footnotetext{
* Corresponding author.

E-mail addresses: luhkartikaningsih@gmail.com (Luh Kartika Ningsih)
} 


\section{Introduction}

The development of technology today is inevitable and becomes a challenge for anyone as competition in the era of globalization. The great transformation of society called development and the increasing life globalization causes Balinese society to change, both in the economic, political, and cultural fields. Each of these changes has a significant impact on the sustainability of people's lives, especially the Balinese. The changes in the economic sector have changed previously which dominated by the agricultural sector are now beginning to shift to the tourism sector, the service industry, and the handicraft industry. The same thing also happened in the cultural sector/culture. There has been a cultural disintegration which creates a cultural crisis, and on the other hand, there has been a cultural integration which forms cultural enrichment process. On progress, this harms development and the high intensity of globalization. It forms behaviours that are increasingly characterized by material, consumeristic, individualistic, and even egoistic behaviours which indirectly are bad traits caused by the development of the globalization.

This phenomenon is similar to how the efforts of the Balinese community, especially the Bali AGA Village can maintain their culture in the swift development of globalization. In its realization, Bali AGA Village can survive and develop against globalization because it has cultural values that remain firmly held as a reference in managing the village so that it can be a village with cultural-value centralization. The development of the AGA Bali Village is inseparable from the role of the Village Institution that managed directly by the Village Apparatus in advancing thee village by not leaving the cultural values that have been passed down.

In the previous study conducted by Goestyari Kurnia Amantha entitled "Analysis of Work Culture in Creating Quality Human Resources", had poor results related to the quality of human resources based on work culture adhered to by employees at the Lampung Provincial Secretariat Organization Bureau. In this study, another factor that wants to be examined to improve the quality of human resources, especially the village apparatus of the Desa Adat Institution through the "Catur Marga-based" Work Culture where the work productivity as the main objective in the management of the Desa Adat Institution. The existence of local wisdom in the implementation of the Work Culture is expected to be able to increase the work productivity of village officials by improving the quality of their human resources.

According to the explanation above, the researcher is interested in conducting research by conducting a study of the value of Work Culture with "Catur Marga-based" by formulating research problems as follows: (1) Is the Work Culture with Catur Marga-based can improve the Quality of Human Resources of Village Apparatus of Bali AGA Buleleng regency? (2) Can the Catur Marga-based Work Culture increase the Work Productivity of the Balinese Village Agencies Village Institute AGA Buleleng Regency? (3) Can Human Resources Management increase the Work Productivity of the Balinese Village Agencies of Bali AGA Buleleng Regency? Thus, the purpose of this study is to determine the role of the "Catur Marga-based" Work Culture to Improve the Quality of Human Resources with Work Productivity as the main objective in the management of the Village Institutions.

Work culture is a philosophy based on the view of life as values that become the nature, habits, and also the driving force cultivated in a group and reflected in attitudes into behaviour, ideals, opinions, views, and actions that manifests as work or work (Gering, Supriyadi, and Triguno: 2001). Work culture is a person's perspective in giving meaning to work and one's perspective on the field they occupy and the moral principles they possess, which foster strong beliefs based on believed values, have a high spirit and are earnest to show the best work performance. This relates to the meaning of Work Culture in the Book "Development of Work Culture of the Ministry of Religion" published by the Indonesian Ministry of Religion Inspectorate General (2009: 23).

Work Culture is formed through a long process. Because in every developing process of work culture, there is a change of old values into new values and it takes time from time to time to build habits by continuing to do improvements continuously for the achievement of ideal work culture. Indirectly, work culture rests on values that are already possessed by the Indonesian nation or society that have been processed in such a way as new values that are used as a basis for behaviour in efforts to face new challenges in the world of work.

According to Ndraha (2002) indicators of Work Culture as below:

a. The basic of assumptions about work, establishment or basic considerations or basic beliefs about work, formed through the construction of syllogistic thinking. The premise is an empirical life experience and a conclusion.

b. Attitudes towards work, humans show various attitudes towards work. Attitude is the tendency of the soul for something. This tendency ranges from fully accepting or rejecting as loud as possible. 
c. Behaviour when working, attitudes towards work, form behavior. Behaviour shows how a person works.

d. Work environment and working tools, In the environment, humans build a comfortable work environment and use tools (technology) to work effectively, efficiently, and productively.

e. Work ethic, ethos is defined as the character or spirit of cultural fundamentals, various expressions that express the beliefs, habits, or behaviour of a community group. So, ethos is related to work culture.

The theory of Catur Marga is a concept that is very commonly known by Hindus as a part of the Tattwa aspect within the basic framework of Hinduism. Originally, Catur Marga theory is generally understood as four ways to get closer to or towards God (Ida Sang Hyang Widhi Wasa) consisting of; 1) Bhakti Marga, 2) Karma Marga, 3) Jnana Marga, and 4) Raja Marga. This teaching develops honesty, discipline, responsibility, caring, polite, environmentally friendly, mutual-cooperation, cooperation, love for peace, responsiveness and pro-active (Adiputra: 2003).

a. Bhakti Marga

The way to God is by showing the Bhakti (filial piety, love to God and fellow). The keyword of Bhakti Marga is "Love All". Love your God, love your family, and love your friends, even you have to love your enemies. Its implementation builds a work culture by surrendering to be able to accept every responsibility which is currently carried out.

b. Karma Marga

The way to God by working or doing selfless service. Do all the work/service as offerings to God and never expect the reward/results. The implementation is to carry out every task and responsibility sincerely and able to finish everything well.

c. Jnana Marga

The way to God by learning Vedic Scriptures. Its implementation is by doing the duties and responsibilities through the practice of religious study by studying, understanding, living, and spreading. Learning knowledge and skills to be able to discuss, provide direction, and transform things.

d. Raja/Yoga Marga

The way to God by doing meditation. Meditation to God and controlling (Tapa). The Implementation that can be learned is able to exercise good self-control used in carrying out the duties and responsibilities.

Human resource management is one of general management which includes aspects of planning, organizing, implementing and controlling. This process contained in the function or production fields, marketing, finance and officialdom for achieving company purposes. Because human resources are considered to have an increasingly important role in achieving company goals, various experiences and research results in the field of human resources are systematically collected in mention human resource management. The term management has a meaning as a collection of knowledge about how to manage human resources (Rivai and Sagala, 2011).

According to Hasibuan (2003), human resource management indicators consist of planning, organizing, directing, controlling, procurement, compensation development, integration, maintenance, discipline, and dismissal.

Basically, productivity includes a mental attitude that always has the view that life today must be better than yesterday and tomorrow is better than today. Sinungan (2003) states that productivity includes a patriotic mental attitude that looks to the future optimistically which comes from self-beliefs that the todays life is better than yesterday and tomorrow is better than today. This attitude will encourage the emergence of effective and productive work, which is very necessary to increase work productivity.

According to Sulistyani and Rosidah (2003), several factors are determining the size of productivity, including: a) Knowledge, Knowledge is an accumulation of the education results process both formally and non-formally that contributes to someone in problem-solving, creative power, including in the completion of work, b) Skill, ability and technical mastery Operational regarding certain fields, which are working in nature, c) Abilities, The ability are formed from several competencies that are owned by everyone, d) Attitude, A habit that is patterned, and e) Behaviours, human's behaviours are determined by habits that have been embedded in self that can support an effective work.

The Quality of human resources is expected to able to carry their duties and responsibilities and increase work productivity based on a culture that understood. Work Culture becomes a habit in every work implementation by every human resource. As well as, the results of research conducted by Haryani and Latifah (2014) states that improving work culture can increase employee work productivity. However, it is different from the results of research conducted by Amantha (2016) which states that there are still poor results related to the quality of human resources based on the work culture adopted by employees at the Regional Secretariat Organization Bureau of Lampung Province. A study conducted by 
Rusminingsih (2010) states that there was a positive and significant effect between human resource development and employee productivity.

\section{Methods}

This research is explanatory in the form of causality among variables. This study examines the causality relationship among Catur Marga-based Work Culture, Human Resource Management, and Work Productivity of the Bali Indigenous Villages Institute AGA Buleleng Regency. The model developed in this study seeks to predict causality among variables. The main goal is to find out the work culture-based on local wisdom in the Desa Adat Institute. This research was conducted at the Bali Aga Traditional Village Institute in Buleleng Regency. Buleleng Regency has 7 Bali Aga villages including Sembiran Village, Julah Village, Sidatapa Village, Cempaga Village, Tigawasa Village, Pedawa Village, Banyuseri Village. The respondents included representatives of village officials from each village institution, including Banjar Adat, STT (Seka Teruna-Teruni), LPMD (Village Community Empowerment Institute), TP. PKK (PKK Driving Team), Bumdes, Linmas, LPD, Subak, and Pecalang. The population in this study was 135 respondents obtained from the total number of devices from each customary village institution.

In collecting the data, the instrument will be used is the questionnaire. There are 135 questionnaires were distributed, all returned and filled out completely. The data that has been collected was analyzed through (Structural Equation Modeling-SEM) based on variance or Component-based SEM, which is well-known as Partial Least Square (PLS) Visual version 3.0.

'In the outer model validity test, that there will be two factors that will be observed in the validity test, namely the value of the loading factor (convergent validity) and the value of cross-loading (discriminant validity). Convergent validity measures the correlation between question items and constructs in research. Individual reflective measures are showed to correlate if more than 0.7 with the construct that you want to measure. However, for the initial research of a measurement scale development of 0.6 loading factor is considered sufficient (Ghozali, 2008). In the initial stage, data testing was performed to determine the accuracy level of the indicator in explaining the exogenous construct in the model using loading factors. According to the following research model path diagram, the results are shown as in Figure 1

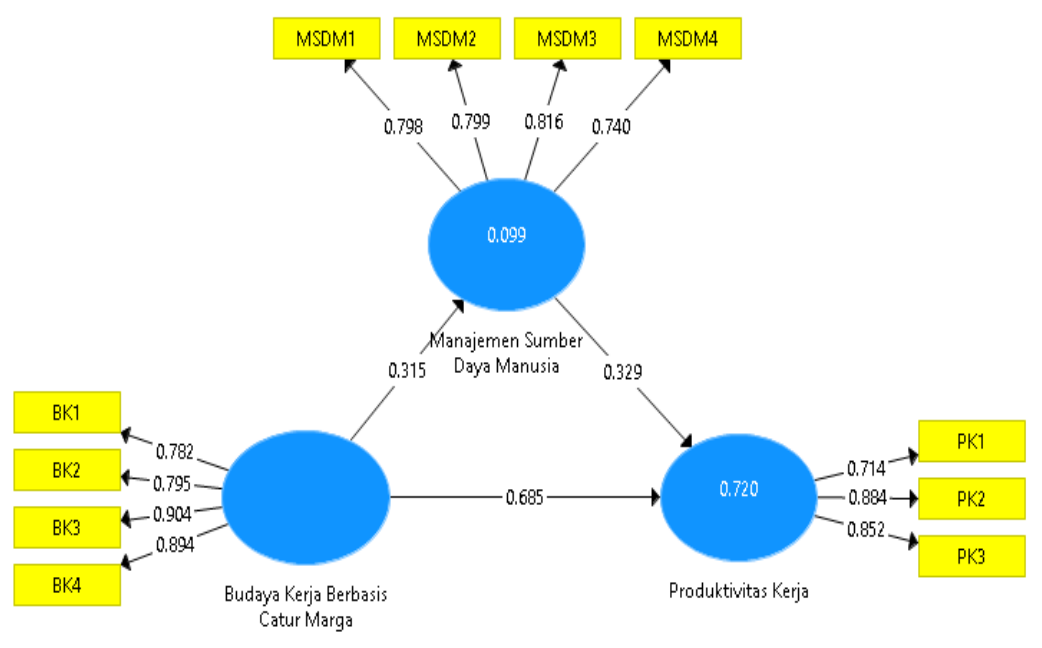

Figure 1. Value of Loading Factor using PLS Path Diagram

According to the picture above, the loading factor shows that the results were convergent validity because all loading factors were> 0.6. Thus, it can be concluded that the convergent validity of all constructs is valid. To strengthen the valid statement of the study construct, researchers also used the Average Variance Extracted (AVE) method. A good construct requires the AVE value to be above 0.50. The AVE test results are described as follows: 
Table 1. AVERAGE VARIANCE EXTRACTED VALUE (AVE)

\begin{tabular}{lr} 
Catur Marga Based Work Culture & 0.715 \\
Human Resource Management & 0.622 \\
\hline Work productivity & 0.672
\end{tabular}

Source: Data processed

Furthermore, reliability can be known from the value of Composite Reliability (CR) and Cronbach's Alpha. The construct is stated to have a high reliability if the Composite Reliability value is above 0.70 and the Cronbach's Alpha value is above 0.60 (Ghozali, 2008). Table 02 presents the Composite Reliability and Cronbach's Alpha values for all variables.

Table 2. COMPOSITE RELIABILITY AND CRONBACH'S ALPHA VALUE

\begin{tabular}{lcc}
\hline & $\begin{array}{c}\text { Cronbach's Alpha } \\
>\mathbf{0 , 6 0}\end{array}$ & $\begin{array}{c}\text { Composite } \\
\text { Reliability } \\
>\mathbf{0 , 7 0}\end{array}$ \\
\hline Catur Marga Based Work Culture & 0.867 & 0.909 \\
\hline Human Resource Management & 0.803 & 0.868 \\
\hline Work productivity & 0.752 & 0.859 \\
\hline
\end{tabular}

The table shows that all constructs in this study produce Composite Reliability values above 0.70 and Cronbach's Alpha values above 0.60 . Therefore, the construct in this study is reliable.

1. Structural Model Testing (Inner Model)

In assessing a model with PLS, it starts by looking at the R-square for each latent dependent variable (Ghozali, 2009). Table 03 is the result of R-square estimation using SmartPLS.

Table 3. R-SQUARE VALUE

\begin{tabular}{lcc}
\hline & R-Square & R-Square Adjusted \\
\hline Human Resource Management & 0.099 & 0.093 \\
\hline Work productivity & 0.720 & 0.716 \\
\hline & & Source: Data processed
\end{tabular}

The influence model of Catur Marga-Based Work Culture on Human Resource Management gives an R-Square value of 0.099 which can be interpreted that the variability of Human Resource Management constructs that can be explained by the construct of Catur Marga-Based Work Culture is $9.9 \%$ while $90.1 \%$ is explained by other variables not examined. Furthermore, the influence model of Catur Marga -based Work Culture on Work Productivity gives an R-Square value of 0.720 which can be interpreted that the variability of Work Productivity constructs that can be explained by the construct of Catur Marga-Based Work Culture is $72 \%$ while $28 \%$ is explained by other variables not examined.

\section{Result and Discussion}

The basis used in testing the hypotheses is the value contained in the output result for inner weight. Table 04 provides estimated outputs for testing structural models.

Table 4. RESULT FOR INNER WEIGHT

\begin{tabular}{lccccc}
\hline & $\begin{array}{c}\text { Original } \\
\text { Sample } \\
\text { (0) }\end{array}$ & $\begin{array}{c}\text { Sample } \\
\text { Mean (M) }\end{array}$ & $\begin{array}{c}\text { Standard } \\
\text { Deviation } \\
\text { (STDEV) }\end{array}$ & $\begin{array}{c}\text { T Statistics } \\
(\mid \mathbf{0} / \text { STDEV|) } \\
\mathbf{> 1 , 9 6}\end{array}$ & $\begin{array}{c}\text { P- } \\
\text { Values }\end{array}$ \\
\hline $\begin{array}{l}\text { Catur Marga-Based Work } \\
\text { Culture -> Human Resource }\end{array}$ & 0.315 & 0.325 & 0.070 & 4.477 & 0.000 \\
\hline
\end{tabular}




\begin{tabular}{lccccc}
\hline Management & & & & & \\
\hline $\begin{array}{l}\text { Catur Marga-Based Work } \\
\begin{array}{l}\text { Culture -> Work } \\
\text { productivity }\end{array}\end{array}$ & 0.789 & 0.791 & 0.025 & 31.010 & 0.000 \\
\hline $\begin{array}{l}\text { Human Resource } \\
\begin{array}{l}\text { Management }->\text { Work } \\
\text { productivity }\end{array}\end{array}$ & 0.329 & 0.329 & 0.045 & 7.338 & 0.000 \\
\hline
\end{tabular}

The results of the first hypothesis testing shows that the relationship between Work Culture based on Catur Marga variables on Human Resource Management shows a parameter of the coefficient of 0.315 with a T-statistics value of 4.477 . This value is greater than $t$ table $(1,960)$. This result means that Catur Marga-based Work Culture has a positive and significant relationship with wth Human Resource Management. Hypothesis 1 is accepted. The better Catur Marga-based Work Culture, the better the quality of Human Resource Management. Improving the Quality of Human Resource Management can be determined by the ability of village officials in the Bali Aga Village Institute of Buleleng Regency in managing self abilities. The ability means Catur Marga-based Work Culture namely Bhakti Marga (building a work culture by submitting to being able to accept every responsibility that is currently carried), Karma Marga (doing every task and responsibility willingly and able to finish everything well), Jnana Marga (doing duties and responsibilities through religious experience with the help of understanding, appreciate, and transferring), Raja / Yoga Marga (able to do a good self-control that can be used in carrying tasks and responsibilities). According to the results on the application of Catur Marga-based Work Culture is able to make a positive contribution to the implementation of each activity in each of the Indigenous Village Institutions. The implementation of Catur Marga in Work Culture directly from the character of Human Resources to be better and always tried to give the best as a village official to the Indigenous Village Institution that was led.

The result of the second hypothesis testing shows that the relationship between Work Culture based on Catur Marga variables and Work Productivity shows a parameter of the coefficient value of 0.789 with a T-statistics value of 31.010. The value is greater than the $\mathrm{T}$ table $(1,960)$. These results indicate that the Work Culture based on Catur Marga has a positive and significant relationship with Work Productivity. The second hypothesis is accepted. The better Catur Marga-based Work Culture, then the higher the Work Productivity. According to loading factor value, it can be known and ensured that the Catur Marga-based Work Culture is able to increase the Work Productivity of the Customary Village Institution. It shows that Human Resources are able to implement Catur Marga in the Work Culture that is carried in every activity so that the Work Productivity can be carried and continue to increase.

The third hypothesis testing result shows that the relationship between the Human Resource Management and Work Productivity variables show the value of the parameter of the coefficient of 0.329 with a T-statistics value of 7.338. This value is greater than $t$ table $(1,960)$. The result shows that Human Resource Management has a positive and significant relationship with Work Productivity. The third hypothesis is accepted. The better Human Resource Management, then higher work productivity. The result shown of this relationship is following each of the customary Village Institution. The ability to hone and improve the self quality was shown by maximizing the capabilities possessed by providing maximum service to the village. The role of human resources in doing the duties and responsibilities is inseparable from the magnitude of the desire to serve the village, to create the welfare of the village and the customary village institutions. Thus, the productivity shown by the village officials shows a very positive value. 


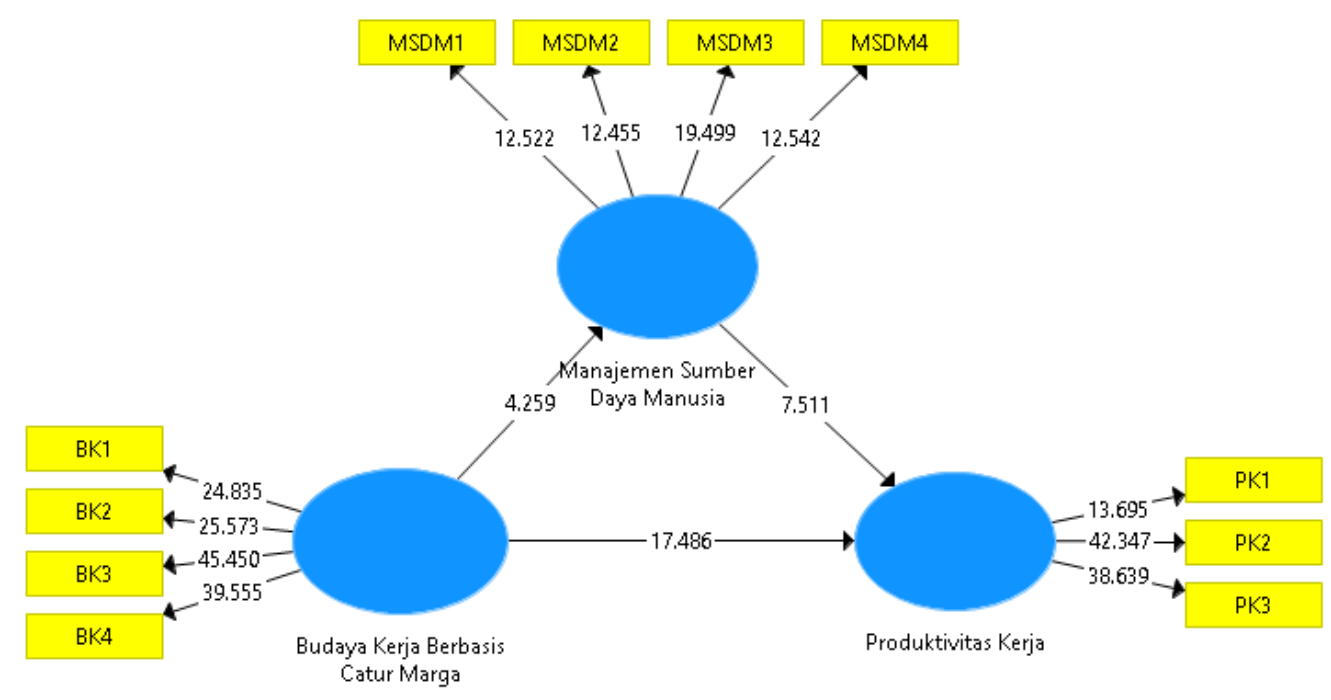

Figure 2. Bootstraping Value

\section{Conclusion}

Based on the results of the research conducted in PDAM Buleleng Regency, it can be concluded that: 1. The results of a significant relationship were shown in the Organizational Culture variable based on Tri Hita Karana on the performance of the employee and Total Quality Management on Performance of Organization. This shows that Organizational Culture based on Tri Hita Karana of Employee Performance and TQM on Organizational Performance has a significant correlation and the direction of a positive or unidirectional relationship and the results of the analysis show that these two relationships have a positive and significant role, so it can be concluded that organizational culture based on Tri Hita Karana and Total Quality Management have their respective significant influence on Employee Performance and Organizational Performance.

2. Different results were shown in the role of Tri Hita Karana-based Organizational Culture on Organizational Performance, HRM on Organizational Performance, HRM on Employee Performance, and TQM on Employee Performance which indicates that there were insignificant results. This shows that there were several factors that have not been able to show positive and significant values on organizational performance and employee performance at the PDAM Office Buleleng Regency.

\section{Reference}

Adiputra, I Gede Rudia. 2003. Pengetahuan Dasar Agama Hindu. Jakarta: STAH Dharma Nusantara.

Amantha, G.K. (2016). Analisis Budaya Kerja dalam Menciptakan Sumber Daya Manusia yang Berkualitas (Studi pada Biro Organisasi Sekretariat Daerah Provinsi Lampung). Universitas Lampung.

Gering, Supriyadi dan Triguno. 2001. Budaya Kerja Organisasi Pemerintah. Jakarta

Ghozali, Imam. 2008. Structural Equation Modeling Metode Alternatif dengan Partial Least Square Edisi Kedua. Badan Penerbit Universitas Diponegoro. Yogyakarta.

Hasibuan, Malayu S.P.2013. Manajemen Ilmu Pengantar. Jakarta: Konsesus

Latfah, Umi dan Sri Haryani. 2014. Pengaruh Motivasi, Pengawasan, Dan Budaya Kerja Terhadap Produktivitas Kerja Karyawan Perusahaan Pengecoran Alumunium "SP". Yogyakarta.

Ndraha, Taliziduhu. 2002. Pengantar Teori Pengembangan Sumber Daya Manusia, Cetakan Pertama, PT. Rineka Cipta: Jakarta

Pengembangan Budaya Kerja Departemen Agama, 2009, Departemen Agama RI Inspktorat Jendral 
Rivai, Veitzal \& Ella Sauvani Sagala. (2011). Manajemen Sumber Daya Manusia Untuk Perusahaan. Jakarta. PT. Raja Gravindo Persada.

Rusminingsih, Diah. 2010. Pengaruh Pengembangan Sumber Daya Manusia Terhadap Produktivitas Kerja Karyawan Pada Pt. Cakra Guna Cipta Malang

Sinungan. M. 2003. Produktivitas Apa dan Bagaimana. Edisi Kedua, Jakarta: Bumi Aksara.

Sudibya, I. G. (1997). Hindu \& Budaya Bali. Denpasar: PT. BP Denpasar

Sulistiyani, Ambar Teguh dan Rosidah. 2009. Manajemen Sumber Daya Manusia Konsep, Teoridan Pengembangan dalam Konteks Organisasi Publik. Yogyakarta: Graha Ilmu. 